\title{
Changes in Carbon Catabolic Pathways during Synchronous Development of Conidiophores of Aspergillus niger
}

\author{
By W. S. NG, J. E. SMITH AND J. G. ANDERSON \\ Department of Applied Microbiology, University of Strathclyde, \\ Glasgow, Scotland
}

(Accepted for publication 26 February 1972)

\begin{abstract}
SUMMARY
Carbon catabolism was studied during the synchronous development of conidiophores of Aspergillus niger. The activities of key enzymes of the Embden-MeyerhofParnas (EMP) and pentose phosphate (PP) pathways were measured and studies of ${ }^{14} \mathrm{CO}_{2}$ production from $\left[\mathrm{I}-{ }^{14} \mathrm{C}\right]-$ and $\left[6-{ }^{14} \mathrm{C}\right]$ glucose were made. The enzyme activities together with the radiorespirometric studies showed that both the EMP and PP pathways were present and operative at all stages of conidiophore development but that the relative activities of the pathways differed. The highest activity of the EMP pathway occurred during the initial period of vegetative growth before any signs of morphological change. High EMP activity and high $6-\mathrm{C} / \mathrm{I}-\mathrm{C}$ ratios were obtained in a medium which did not support conidiophore initiation but allowed vegetative growth to occur. In contrast, high activity of the PP pathway and very low 6-C/I-C ratios accompanied each stage of conidiophore development. The results suggest that the PP pathway predominates during conidiophore development of this fungus.
\end{abstract}

\section{INTRODUCTION}

Radiorespirometric studies with Endothia parasitica (McDowell \& DeHertogh, I968) and Aspergillus nidulans (Carter \& Bull, 1969) indicated an enhanced contribution of the PP pathway prior to and during conidiation. Similarly, an active PP pathway was found to operate throughout conidiogenesis in Neurospora crassa (Turian, 1962), while Daly, Sayre \& Pazur (1957) have demonstrated that the PP pathway was the major respiratory pathway during conidiation of the obligate rust fungus Puccinia carthami growing on safflower.

Recent studies on carbon catabolism during the growth cycle of Aspergillus niger (Smith, Valenzuela-Perez \& $\mathrm{Ng}$, 197I) growing in flask culture indicated that the contribution of the EMP pathway was highest in conidiating mycelium, whereas the contribution of the PP pathway was highest in young vegetative mycelium growing under conditions that would not induce conidiation (Valenzuela-Perez \& Smith, 197I). It was considered that the use of glutamate in these experiments to induce conidiation masked the high reductive biosynthetic needs of conidiation and it is probable that if a tricarboxylic acid cycle intermediate had been used to induce conidiation (Galbraith \& Smith, 1969) there would have been a higher involvement of the PP pathway during conidiation of this fungus.

This report describes the changes that occurred in certain enzymes of the EMP and PP pathways during the initiation and synchronous development of conidiophores of Aspergillus niger. Enzyme determinations were also carried out on extracts of mycelium grown in a medium which did not support conidiophore initiation but did allow normal vegetative growth to occur. In view of the difficulties involved in assessing the significance of enzyme studies in vitro the measurements of enzyme activities were supplemented with measurements of ${ }^{14} \mathrm{CO}_{2}$ produced from $\left[\mathrm{I}^{14} \mathrm{C}\right]-$ and $\left[6-{ }^{14} \mathrm{C}\right] \mathrm{glucose}$. 


\section{METHODS}

Organism and cultural conditions. The fungus used was Aspergillus niger van Tieghem (IMI. 4I873) and the maintenance of stock cultures and the production of conidia were as previously described (Galbraith \& Smith, 1969). Growth and synchronous development of conidiophores and conidia were obtained by means of a replacement fermentor culture technique (Anderson \& Smith, I971). Several media were used in this technique and all contained the following minerals in I 1 distilled water: $\mathrm{KH}_{2} \mathrm{PO}_{4}, \mathrm{I} \cdot 0 \mathrm{~g} ; \mathrm{MgSO}_{4} \cdot 7 \mathrm{H}_{2} \mathrm{O}$, $0.25 \mathrm{~g} ; \mathrm{CuSO}_{4} \cdot 5 \mathrm{H}_{2} \mathrm{O}, 0.234 \mathrm{mg} ; \mathrm{FeSO}_{4} .7 \mathrm{H}_{2} \mathrm{O}, 6.32 \mathrm{mg} ; \mathrm{ZnSO}_{4} \cdot 7 \mathrm{H}_{2} \mathrm{O}, \mathrm{I} \cdot \mathrm{I} \mathrm{mg} ; \mathrm{MnCl}_{2} \cdot 4 \mathrm{H}_{2} \mathrm{O}$, $3.5 \mathrm{mg} ; \mathrm{CaCl}_{2}, 46.7 \mathrm{mg}$. The medium for growth of the fermentor inoculum contained in I $1 \mathrm{M}$ (mineral solution): $\left(\mathrm{NH}_{4}\right)_{2} \mathrm{SO}_{4}, 3.96 \mathrm{~g}$; and glucose, $20 \mathrm{~g}$. The $\mathrm{pH}$ was adjusted to 2.3 for loose colonial growth. The medium for the initial phase of growth in the fermentor (LN medium) contained in $\mathrm{I} 1 \mathrm{M}:\left(\mathrm{NH}_{4}\right)_{2} \mathrm{SO}_{4}, 0.66 \mathrm{~g}$; and glucose, $\mathrm{I0} .0 \mathrm{~g}$. The initial $\mathrm{pH}$ of this medium was 4.5 and was not further adjusted. The first replacement medium (MN+citrate medium) contained in $\mathrm{I} 1 \mathrm{M}:\left(\mathrm{NH}_{4}\right)_{2} \mathrm{SO}_{4}, \mathrm{I} \cdot 98 \mathrm{~g}$; and citric acid, $\mathrm{I} 2 \cdot 6 \mathrm{~g}$. The $\mathrm{pH}$ was adjusted to 3.0 with $\mathrm{NaOH}$. The second replacement medium (glucose nitrate medium) contained in I 1 distilled water: $\mathrm{NaNO}_{3}, 2.55 \mathrm{~g}$; glucose, $20 \mathrm{~g}$; and mineral salts as for $\mathrm{M}$ except that $\mathrm{KH}_{2} \mathrm{PO}_{4}$ was increased to $\mathrm{I} 2 \cdot 96 \mathrm{~g}$ and $\mathrm{K}_{2} \mathrm{HPO}_{4}, \mathrm{I} \cdot \mathrm{I} 3 \mathrm{~g}$ was included.

By means of the medium replacement technique the differentiation of the conidiophore can be divided into four distinct morphogenetic stages: (i) conidiophore initiation; (ii) conidiophore growth; (iii) vesicle and phialide formation; and (iv) conidiospore production. Initiation and growth of the conidiophores occurs in the original LN medium. The first medium replacement at $36 \mathrm{~h}$ induces vesicle and phialide formation and the second medium replacement at $56 \mathrm{~h}$ leads to heavy conidia production. Without medium replacement the conidiophores will not develop beyond the immature stalk stage. Conidiophore initiation did not occur in LN medium under continuous oxygen limited conditions (LNO medium), although vegetative growth was not restricted. Enzyme determinations were carried out on extracts from all stages of the synchronous development of the conidiophores and also from the completely vegetative mycelium from LNO medium.

Preparation of extracts. The mycelium was harvested by filtration, washed free of medium, pressed between filter papers to remove excess water, and disrupted by means of a glass homogenizer attached to an M. S. E. Waring blender rotor shaft (Watson \& Smith, 1967). A ratio of $\mathrm{I} g$ wet weight of mycelium to $\mathrm{I} / \mathrm{ml}$ extraction medium containing $0.05 \mathrm{M}$-tris$\mathrm{HCl}$ buffer, $\mathrm{pH} 7 \cdot 0$, was used and all operations were carried out between $\mathrm{O}$ and $4{ }^{\circ} \mathrm{C}$. The homogenate was centrifuged at $26000 \mathrm{~g}$ for $\mathrm{I} 5 \mathrm{~min}$ and the supernatant used immediately for enzymatic determinations. For comparative enzyme studies equal weights of fresh mycelium were used, the conditions of extraction rigorously standardized, and the final cytoplasmic fractions made to equal volumes.

Enzyme assays. A Unicam SP 800 spectrophotometer with scale expansion, constanttemperature cell housing, automatic cell changer, and constant-wavelength accessory was used to measure the enzymatic activities of the extracts. All assays were carried out at $25^{\circ} \mathrm{C}$ by observing either the oxidation or the reduction of nicotinamide adenine dinucleotides (NAD and NADP). Enzyme activities were measured by noting the change in absorbance at $340 \mathrm{~nm}$ which was recorded continuously for 3 to $5 \mathrm{~min}$ and the results calculated from the linear portion of the curve of absorbance against time. Endogenous activity, which was determined using an assay system minus substrate, was always subtracted. All activities were assayed at optimum $\mathrm{pH}$ and at substrate concentrations which ensured enzyme saturation and extracts were added at concentrations which limited the rate of the reaction. The en- 


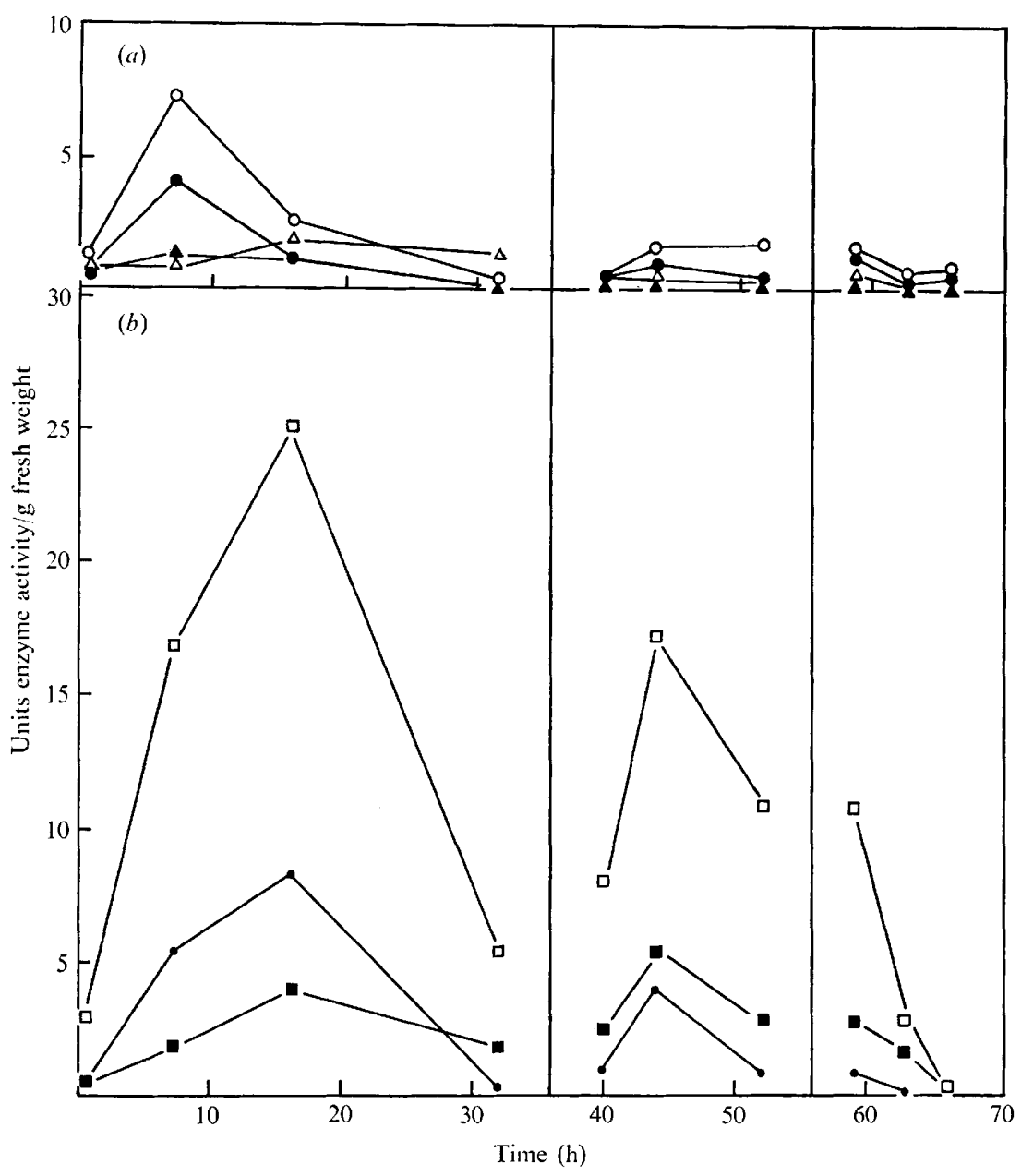

Fig. I. Changes in activities of EMP and PP pathway enzymes from mycelium from LN and replacement media. All concentrations of enzymes are expressed as units of enzyme activity/g fresh weight of mycelium. (a) EMP pathway enzymes: 9 , hexokinase; $\bigcirc$, phosphofructokinase; $\triangle$, pyruvate kinase; and $\boldsymbol{\Delta}$, fructose diphosphatase. (b) PP pathway enzymes: $\square$, glucose-6-phosphate dehydrogenase; $\mathbf{\square}$, phosphogluconate dehydrogenase; $\bullet$, transketolase.

zymes were stable for several hours if kept at o to $4{ }^{\circ} \mathrm{C}$. Enzyme activities were measured in at least three, usually six, separate experiments.

Hexokinase was assayed as described by Gibbs \& Turner (I964), phosphofructokinase by Slater (1953), fructose diphosphatase by Rosen (1966), pyruvate kinase by Bucher \& Pfleiderer (I955), glucose 6-phosphate dehydrogenase and 6-phosphogluconate dehydrogenase by Kornberg \& Horecker (I955) as modified by Waygood \& Rohringer (I964) and transketolase by Casselton (I966).

Protein was assayed by the method of Lowry, Rosebrough, Farr \& Randall (I95I).

Presentation of enzyme results. One unit of enzyme activity is defined as the amount of enzyme which converts I $\mu \mathrm{mol}$ of substrate $/ \mathrm{min}$ at $25^{\circ} \mathrm{C}$. An extinction coefficient of $6.22 \times 10^{6}$ $\mathrm{cm}^{2} / \mathrm{mol}$ of nucleotide at $340 \mathrm{~nm}$ (Horecker \& Kornberg, I948; Wold \& Ballou, 1957) was used in these calculations. Activity was related either to fresh weight of mycelium and 


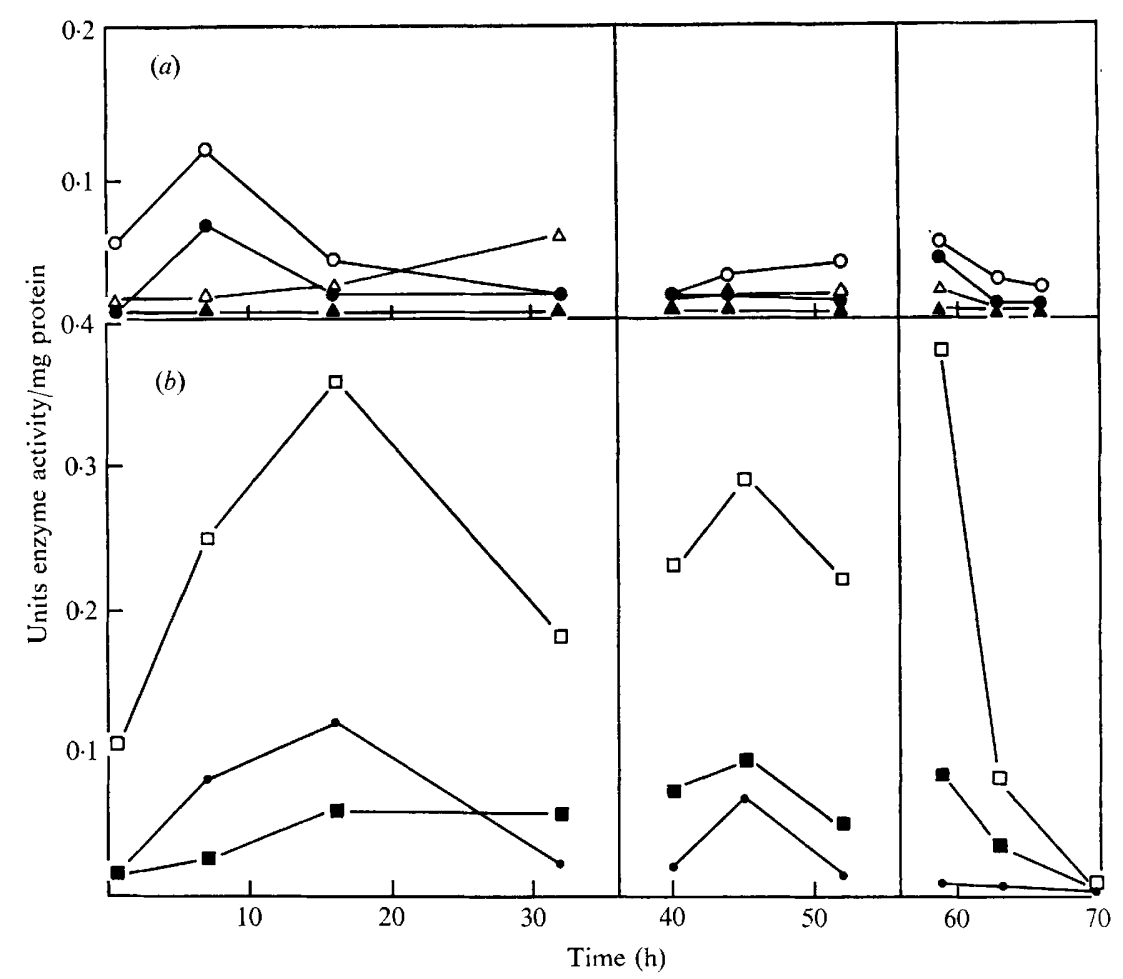

Fig. 2. Changes in activities of EMP and PP pathway enzymes from mycelium from $L N$ and replacement media. All concentrations of enzymes are expressed as units of enzyme activity/mg protein (specific activity). (a) EMP pathway enzymes; (b) PP pathway enzymes. Symbols as in Fig. I.

expressed as units of activity/g mycelium or as specific activity and expressed as units of activity/mg protein. In Fig. I and 2 vertical lines divide the diagrams at points of medium replacement.

Radiorespirometry. Radiorespirometric studies were carried out as previously described (Smith et al. 197I). The interpretation of the data is based on the assumption that the first carbon atom of glucose is oxidized preferentially to $\mathrm{CO}_{2}$ when still a constituent atom of the $\mathrm{C}_{6}$ compound (6-phospho-D-gluconate) and not a further breakdown product of glucose. Therefore, it is essential to limit the time of the experiment and for this reason the cumulative radiochemical recoveries were taken at the point of substrate exhaustion. At this time it is considered that the different catabolic sequences are minimized thus making the ${ }^{14} \mathrm{CO}_{2}$ data reliable for pathway estimation. Preliminary experiments showed that the $\mathrm{I} \mu \mathrm{mol}$ of glucose used in these experiments was completely utilized within $\mathrm{I} h$ of incubation. Radiorespirometric analyses were carried out at 0.5 and $\mathrm{I} h$ and in general the ${ }^{14} \mathrm{CO}_{2}$ readings were proportional.

\section{RESULTS}

Activities of EMP pathway enzymes during growth in $L N$ and replacement media

The activities of the enzymes hexokinase (HK), phosphofructokinase (PFK) and pyruvate kinase (PK) together with the gluconeogenic enzyme fructose diphosphatase (FDP) in extracts of mycelium during synchronous development of conidiophores are shown in Fig. I and 2. 


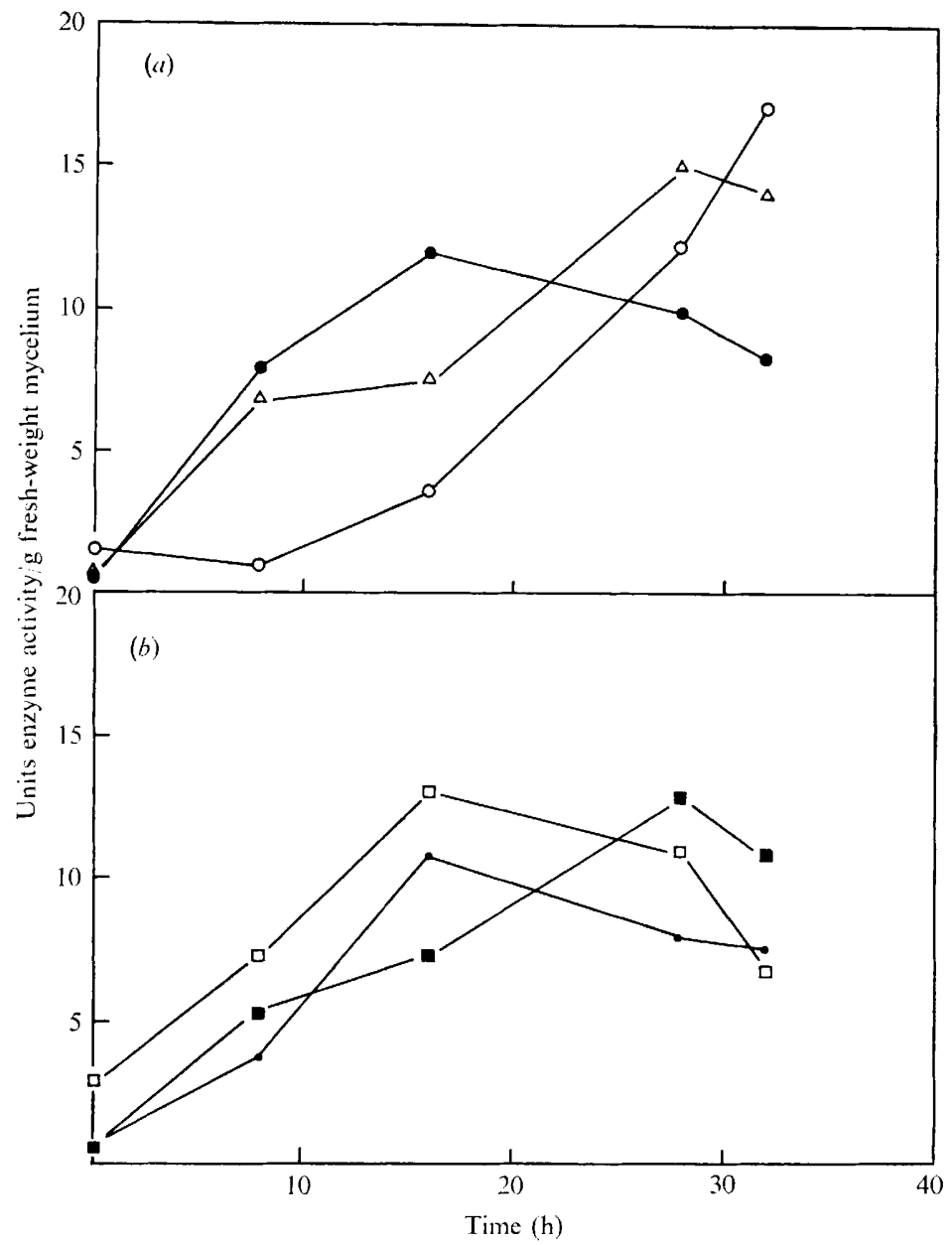

Fig. 3. Changes in activities of EMP and PP pathway enzymes from mycelium from LNO medium. All concentrations of enzymes are expressed as units of enzyme activity/g fresh weight of mycelium.

(a) EMP pathway enzymes; (b) PP pathway enzymes. Symbols as in Fig. I.

The pattern of activity of HK and PFK was similar in LN medium both initially increased in activity to $7 \mathrm{~h}$ and then decreased. PK activity remained low during the early stages of growth in this medium and then increased slightly. The activity of FDP remained low throughout.

In the first replacement medium $\mathrm{HK}$ and $\mathrm{PK}$ remained consistently low, whereas the activity of PFK increased. FDP was present only in trace levels.

In the second replacement medium the specific activity of HK, PFK and PK increased initially and then rapidly decreased. FDP showed a pattern of constant low activity. On a fresh weight basis there was a general pattern of decrease in activity.

\section{Activities of PP pathway enzymes during growth in $L N$ and replacement media}

The activities of the enzymes glucose 6-phosphate dehydrogenase (G6PDH), 6-phosphogluconate dehydrogenase (PGADH) and transketolase (TK) in extracts of mycelium during synchronous development of conidiophores are shown in Fig. I and 2.

In $\mathrm{LN}$ medium the activities of each enzyme increased up to $16 \mathrm{~h}$ and then decreased. 
Table $\mathrm{I}$. Changes in 6-C/I-C ratios during growth in LN, replacement, and LNO media

\begin{tabular}{|c|c|c|c|c|}
\hline $\begin{array}{c}\text { Age of } \\
\text { culture (h) }\end{array}$ & Isotope & $\begin{array}{l}\text { C.p.m./2.5 mg dry wt/h } \\
\text { Replacement culture }\end{array}$ & $\begin{array}{c}\text { Recovery } \\
(\%)\end{array}$ & $6-C / 1-C$ \\
\hline \multirow[t]{2}{*}{ Inoculum } & $\begin{array}{l}\mathrm{I}-\mathrm{C} \\
6-\mathrm{C}\end{array}$ & $\begin{array}{r}52057 \\
38373\end{array}$ & $\left.\begin{array}{l}4 \cdot I \\
2 \cdot 8\end{array}\right\}$ & 0.73 \\
\hline & & LN medium & & \\
\hline 7 & $\begin{array}{l}I-C \\
6-C\end{array}$ & $\begin{array}{r}237227 \\
74183\end{array}$ & $\left.\begin{array}{r}8.8 \\
5.5\end{array}\right\}$ & $0.3 \mathrm{I}$ \\
\hline 16 & $\begin{array}{l}\mathrm{I}-\mathrm{C} \\
6-\mathrm{C}\end{array}$ & $\begin{array}{l}60876 \\
\text { I } 1849\end{array}$ & $\left.\begin{array}{l}4.8 \\
0.8\end{array}\right\}$ & 0.19 \\
\hline 26 & $\begin{array}{l}\mathrm{I}-\mathrm{C} \\
6-\mathrm{C}\end{array}$ & $\begin{array}{r}181473 \\
26152\end{array}$ & $\left.\begin{array}{r}14 \cdot 0 \\
1 \cdot 9\end{array}\right\}$ & 0.14 \\
\hline 32 & $\begin{array}{l}\mathrm{I}-\mathrm{C} \\
6-\mathrm{C}\end{array}$ & $\begin{array}{r}137270 \\
71757\end{array}$ & $\left.\begin{array}{r}10.9 \\
5.3\end{array}\right\}$ & 0.52 \\
\hline \multicolumn{5}{|c|}{ Ist replacement medium } \\
\hline 40 & $\begin{array}{l}I-C \\
6-C\end{array}$ & $\begin{array}{r}\text { I34 } 344 \\
30953\end{array}$ & $\left.\begin{array}{r}10 \cdot 6 \\
2 \cdot 3\end{array}\right\}$ & 0.23 \\
\hline 52 & $\begin{array}{l}I-C \\
6-C\end{array}$ & $\begin{array}{r}\text { I21 } 823 \\
29485\end{array}$ & 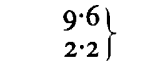 & 0.24 \\
\hline \multicolumn{5}{|c|}{ 2nd replacement medium } \\
\hline 59 & $\begin{array}{l}1-C \\
6-C\end{array}$ & $\begin{array}{r}\text { IOI } 818 \\
13577\end{array}$ & $\left.\begin{array}{l}8 \cdot 1 \\
I \cdot 0\end{array}\right\}$ & 0.13 \\
\hline 63 & $\begin{array}{l}\mathrm{I}-\mathrm{C} \\
6-\mathrm{C}\end{array}$ & $\begin{array}{r}133394 \\
29972\end{array}$ & $\left.\begin{array}{r}10.5 \\
2.2\end{array}\right\}$ & 0.22 \\
\hline \multicolumn{5}{|c|}{ LNO medium } \\
\hline 8 & $\begin{array}{l}I-C \\
6-C\end{array}$ & $\begin{array}{l}42394 \\
23504\end{array}$ & $\left.\begin{array}{l}3 \cdot 3 \\
1 \cdot 7\end{array}\right\}$ & 0.55 \\
\hline 26 & $\begin{array}{l}I-C \\
6-C\end{array}$ & $\begin{array}{l}\text { 61 } 823 \\
26854\end{array}$ & $\left.\begin{array}{l}4 \cdot 9 \\
1 \cdot 9\end{array}\right\}$ & 0.43 \\
\hline 32 & $\begin{array}{l}\mathrm{I}-\mathrm{C} \\
6-\mathrm{C}\end{array}$ & $\begin{array}{l}50163 \\
34209\end{array}$ & $\left.\begin{array}{l}3.9 \\
2 \cdot 5\end{array}\right\}$ & 0.68 \\
\hline
\end{tabular}

Total activity in each flask: $\left[\mathrm{I}^{-14} \mathrm{C}\right] \mathrm{glucose}$, I 259607 c.p.m. $(0 \cdot 4 \mu \mathrm{Ci})$; $\left[6-{ }^{14} \mathrm{C}\right]$ glucose, I 344645 c.p.m. $\left(0^{\circ} 4 \mu \mathrm{Ci}\right)$

After each medium replacement there was an initial increase in enzyme activity followed by a steady decrease.

At all phases of development the activities of the PP pathway enzymes were much in excess of the EMP pathway enzymes.

\section{Activities of EMP and PP pathway enzymes during growth in LNO medium}

The activities of the EMP pathway enzymes were all considerably higher in this medium than in LN medium (Fig. 3). The activities of HK and PK increased rapidly in the early stages of growth; whereas HK decreased after $16 \mathrm{~h}$ PK continued to increase. PFK was initially low in activity but steadily increased throughout the experimental period. FDP remained at trace levels throughout.

G6PDH and TK both increased until $16 \mathrm{~h}$ and then decreased while the activity of PGADH steadily increased throughout the experimental period. 


\section{Respirometric analysis of 6-C/I-C ratios during growth in $L N$, replacement, and LNO media}

When glucose is metabolized through the EMP pathway carbon atoms I and 6 are equivalent and the 6-C/I-C ratio of isotopic carbon produced should be equal to unity. However, if the PP pathway is also functioning this ratio should give values below one (Beevers \& Gibbs, 1954). The value of the ratio will depend on the relative contribution of each pathway.

The 6-C/I-C ratio altered significantly during synchronous development of the conidiophores. The ratio was highest in the initial inoculum decreasing to a low level in LN medium at $26 \mathrm{~h}$ and then increasing considerably at $32 \mathrm{~h}$ (Table $\mathrm{I}$ ).

In the first replacement medium the ratio again dropped and remained constant over $12 \mathrm{~h}$. A further decrease occurred in the ratio in the second replacement medium followed by a slight increase after $7 \mathrm{~h}$.

In LNO medium the ratios remained consistently high throughout the experimental period.

\section{DISCUSSION}

Numerous studies have dealt specifically with quantitative changes in enzyme levels during differentiation and suggestive correlations have been described between the increasing levels of specific enzymes and the changing requirements of differentiation (see Smith \& Galbraith, 1971). However, it is still uncertain whether enzyme activity in vitro always truly reflects enzyme activity in vivo. In the present experiments enzyme determinations in vitro were coupled with the radiorespirometric analysis of glucose dissimilation in vivo and when taken together give a more reliable estimation of the changes in vivo in glucose catabolism during differentiation.

The enzymes of the PP and EMP pathways were active throughout the entire experimental period. In general, during conidiophore differentiation the PP pathway enzymes were higher in activity than the EMP pathway enzymes and when considered with the radiorespirometric results strongly imply that the direct oxidation of glucose through the PP pathway may be of considerable importance during conidiophore development in Aspergillus niger. These observations are in substantial agreement with other studies on glucose catabolism during fungal differentiation (Daly et al. I957; Turian, 1962; McDowell \& DeHertogh, I968; Carter \& Bull, 1969), and would indicate a major role for the PP pathway and its intermediary products (pentoses, $\mathrm{NADPH}_{2}$ ) during differentiation.

The observation that at any one time G6PDH was the most active PP pathway enzyme is of interest. Osmond \& Apprees (1969) have pointed out that this enzyme may be involved in the control of the pathway. Similarly, a number of other reports have shown that an increase of the PP pathway was accompanied by an increase of this enzyme and that treatments that lead to the oxidation of $\mathrm{NADPH}_{2}$ caused an immediate stimulation of G6DPH (Holzer \& Witt, 1960; Novello \& McLean, 1968).

In LN medium TK was the second most active enzyme, and Venkataraman \& Racker (196I) have indicated that an increase in activity of TK would prevent the accumulation of erythrose-4-phosphate which is a known inhibitor of glucose-6-phosphate isomerase, thus allowing the increase in PP pathway activity without due inhibition of the EMP pathway. This may be the situation in LN and LNO media where the activity of both pathways was high.

The high activity of the PP pathway after replacement into the nitrate medium (second 
replacement) may be due to the presence of the nitrate since nitrate assimilation involves the utilization of $\mathrm{NADPH}_{2}$ by nitrate reductase and the availability of this nucleotide is considered to limit the pathway (Osmond \& Apprees, 1969).

No conclusions can be made regarding the role of the EMP pathway during conidiophore development. The activity of the EMP enzymes paralleled the total glucose concentration in the medium. In the early stages in $\mathrm{LN}$ medium and in the second replacement medium, where glucose was also the carbon source, enzyme activity was highest decreasing as the glucose became exhausted (Anderson \& Smith, I97I). In the first medium replacement where citrate was the carbon source and also at the time when active differentiation was occurring the EMP pathway enzymes were low in activity.

The partial anaerobic conditions that prevail in $\mathrm{LN}$ medium for the initial $\mathrm{I} 4 \mathrm{~h}$ (Anderson \& Smith, I971) may also influence the activity of the EMP enzymes. In LNO medium the activity of EMP pathway enzymes was initially high and increased as the growing conditions became more anaerobic. Similar observations on the influence of oxygen tension on glycolysis have been made for Aspergillus niger (Franke, Eichhorn \& Jilge, 1963) and for Fusarium lini (Heath, Nasser \& Koffler, 1956) and continued high EMP activity may suppress morphological differentiation (Schwalb \& Miles, 1967; Crocken \& Tatum, 1968; Warburg, Geissler \& Lorenz, I968).

The activity of the PP pathway, as measured by the 6-C/I-C ratio, was lower in LNO medium than in LN medium, although the specific activities of the respective enzymes were not markedly affected. Fluorometric analysis of the glycolytic intermediates of this system has shown that the concentration of glucose-6-phosphate (G-6-P) is, in general, much higher in mycelium from LNO medium than that from $\mathrm{LN}$ medium (Smith \& $\mathrm{Ng}$, I972), e.g. in LN medium at 7 and $\mathrm{I} 6 \mathrm{~h}$ the concentrations of G-6-P were 0.003 and $0.007 \mu \mathrm{mol} / \mathrm{g}$ dry weight respectively, whereas in LNO medium the corresponding values were 0.145 and 0.045 $\mu \mathrm{mol} / \mathrm{g}$ dry weight. Thus in LN medium the low steady state level of G-6-P coupled with a possible high affinity for G-6-P of G6PDH may regulate the pathway of glucose catabolism. In LNO medium the higher steady state levels of G-6-P may allow a greater proportion to be metabolized by the EMP pathway. Thus the partial anaerobic conditions in LNO medium may act by stimulating G-6-P formation and not by directly inhibiting PP enzyme activity.

However, it is probable that conidiation requires the establishment of a balance between oxidative and glycolytic pathways and that conidiation can be considered to be a morphogenetic expression of the Pasteur effect (Turian, 1969).

The present results differ in some detail from those obtained in the previous study on carbon catabolism during differentiation of Aspergillus niger (Smith et al. I97I). It is difficult to make a true comparison between the systems, each of which ultimately leads to conidiation, because of the changing environmental conditions imposed in the fermentor studies. However, unpublished results have suggested that transcription for conidiation takes place early in each growth cycle, viz. between 32 and $36 \mathrm{~h}$ in the glutamate medium (Smith et al. I97I) and approximately in the middle phase in LN medium. Thus, if a comparison is made between the first $48 \mathrm{~h}$ of growth in glutamate medium and the growth phase in LN medium some interesting observations can be made. In each case the patterns of activity of $\mathrm{HK}$ and PK are similar, whereas PFK shows a steady increase in the glutamate medium and a decrease in LN medium. How much the changes in PFK are related to glucose depletion or changing aeration rates is not yet clearly understood.

The presence of glutamate must undoubtedly influence the contribution of the PP pathway since one of the main functions of this pathway is to produce the $\mathrm{NADPH}_{2}$ essential for reductive biosynthesis, in particular, amino acid synthesis from inorganic sources. The 
ability of the mycelium to incorporate glutamic acid from the medium directly into the amino acid pool could greatly reduce the involvement of the PP pathway for this particular aspect of cellular biosynthesis. Furthermore, the presence of glutamate in the medium could particularly mask the high biosynthetic needs of the differentiating system. Although the contribution of the PP pathway is always less in the glutamate medium than in LN medium there is a marked increase in the PP pathway in the former as measured by $6-\mathrm{C} / \mathrm{I}-\mathrm{C}$ ratios as differentiation progresses (Smith et al. I97I).

\section{REFERENCES}

ANDERSON, J. G. \& SMith, J. E. (197I). Synchronous initiation and maturation of Aspergillus niger conidiophores in culture. Transactions of the British Mycological Society 56, 9-29.

Beevers, H. \& GibBs, M. (1954). The direct oxidation pathway in plant respiration. Plant Physiology 29, 322-324.

Bucher, T. \& Pfleiderer, G. (1955). Pyruvate kinase from muscle. Methods in Enzymology $\mathbf{1}$, 435-44I.

CARTER, B. L. A. \& BulL, A. T. (I969). Studies of fungal growth and intermediary carbon metabolism under steady and non-steady state conditions. Biotechnology and Bioengineering II, 785-804.

CASSElton, P. J. (1966). Enzymes of the Embden-Meyerhof-Parnas and pentose phosphate pathways in Polyporus brumalis extracts. Journal of Experimental Botany 17, 579-589.

Crocken, B. \& Tatum, E. L. (I968). The effect of sorbose on metabolism and morphology of Neurospora. Biochimica et biophysica acta $\mathbf{1 5 6}, \mathrm{x}-8$.

Daly, J. M., SAYRe, R. M. \& PAZUR, J. H. (1957). The hexosemonophosphate shunt as the major respiratory pathway during sporulation of rust of safflower. Plant Physiology 32, 44-48.

Franke, W., EichHoRN, G. \& JiLGE, G. (1963). Zum enzymatischen Umsatz von $\mathrm{C}_{2}$ Säuren durch Mikroorganismen. IV. Beobachtungen zur substratinduzierten Bildung verschiedener glyoxylatumsetzender und bildender Enzyme durch Aspergillus niger. Archiv für Mikrobiologie 45, 314-322.

Galbraith, J. C. \& SMith, J. E. (1969). Sporulation of Aspergillus niger in submerged liquid culture. Journal of General Microbiology 59, 3I-45.

GibBs, M. \& TURnER, E. F. (1964). Enzymes of glycolysis. In Modern Methods of Plant Analysis, vol. 7, pp. 52 I-545. Berlin, Göttingen and Heidelberg: Springer-Verlag.

Heath, E. C., NAsser, D. \& Koffler, H. (1956). Biochemistry of filamentous fungi. III. Alternative routes for the breakdown of glucose by Fusarium lini. Archives of Biochemistry and Biophysics 64, 80-87.

Holzer, H. \& WitT, I. (I960). Beschleunigung des oxydativen Pentose-Phosphatcyclus in Hefezellen durch Ammoniumsalze. Biochemica et biophysica acta 38, $163-164$.

HORECKER, B. L. \& KORNBERG, A. (1948). The extinction coefficients of the reduced band of pyridine nucleotides. Journal of Biological Chemistry 175, 385-390.

KornberG, A. \& HoReCKer, B. L. (1955). Glucose-6-phosphate dehydrogenase. Methods in Enzymology I, 323-337.

Lowry, O. H., Rosebrough, N. J., FarR, A. L. \& Randall, R. J. (1951). Protein measurement with Folin phenol reagent. Journal of Biological Chemistry 193, 265-275.

MCDowell, L. L. \& DeHertogh, A. A. (I968). Metabolism of sporulation in filamentous fungi. I. Glucose and acetate oxidation in sporulating and non-sporulating cultures of Endothia parasitica. Canadian Journal of Botany 46, 449-45I.

Novello, F. \& MCLEAN, P. (1968). The pentose phosphate pathway of glucose metabolism; measurement of the non-oxidative reactions of the cycle. Biochemical Journal ro7, 775-79r.

Osmond, C. B. \& Apprees, T. (1969). Control of the pentose phosphate pathway in yeast. Biochima et biophysica acta $184,35-42$.

Rosen, O. M. (1966). Purification and properties of fructose I,6 diphosphatase from Polysphondylium pallidum. Archives of Biochemistry and Biophysics 114, 3 I-37.

Schwalb, M. N. \& Miles, P. G. (1967). Morphogenesis of Schizophyllum commune. II. Effect of microaerobic growth. Mycologia 59, 610-622.

SLATER, E. C. (1953). Spectrophotometric determination of fructose-I,6-diphosphate hexosemonophosphates, adenosinetriphosphate and adenosinediphosphate. Biochemical Journal 53, I57-167.

SMITH, J. E. \& Galbraith, J. C. (I97I). Biochemical and physiological aspects of differentiation in the fungi. Advances in Microbial Physiology 5, 45-1 34 . 
SMITH, J. E. \& NG, W. S. (1972). Fluorometric determination of glycolytic intermediates and adenylates during synchronous development of Aspergillus niger. Canadian Journal of Microbiology, (in the press).

Smith, J. E., Valenzuela-Perez, J. \& NG, W. S. (197I). Changes in activities of the Embden-MeyerhofParnas and pentose phosphate pathways during the growth cycle of Aspergillus niger. Transactions of the British Mycology Society 57, 93-I0I.

TURIAN, G. (1962). The hexose monophosphate shunt as an alternate metabolic pathway for conidial differentiation in Neurospora. Neurospora Newsletter 2, 15.

TuRIAN, G. (1969). Differenciation fongique. Paris: Masson and Co.

Valenzuela-Perez, J. \& SMith, J. E. (197I). The role of glycolysis in sporulation of Aspergillus niger in submerged culture. Transactions of the British Mycological Society 57, I I I-I I9.

Venkataraman, R. \& RaCker, E. (196I). Mechanism of action of transaldolase. I. Crystallization and properties of yeast enzymes. Journal of Biological Chemistry 236, I 876-1882.

WarburG, O., Geissler, A. W. \& LoREnZ, S. (1968). Oxygen the creator of differentiation. In Aspects of Yeast Metabolism, pp. 327-336. Edited by A. K. Mills. Philadelphia: F. A. Davies Co.

WATSON, K. \& SMIтH, J. E. (1967). Oxidative phosphorylation and respiratory control in mitochondria from Aspergillus niger. Biochemical Journal ro4, 332-339.

WAYGoOd, E. R. \& RoHringer, R. (1964). Enzymes of the pentose pathway. In Modern Methods of Plant Analysis, vol. 7, pp. 546-568. Berlin, Göttingen and Heidelberg: Springer-Verlag.

Wold, F. \& Ballou, C. E. (1957). Studies on the enzyme enolase. II. Kinetic studies. Journal of Biological Chemistry 227, 313-328. 